\title{
The Development Model of Street Girls Empowerment in Surabaya
}

\section{Dr. Raden Roro Nanik Setyowati}

Faculty of Social Sience, State University of Surabaya, 60231, Surabaya, Indonesia

Email: rr_nanik_setyowati@yahoo.com

\section{M.A Ali Imron}

Faculty of Social Sience, State University of Surabaya, 60231, Surabaya, Indonesia

Email: aimron8883@gmail.com

Doi:10.5901/mjss.2016.v7n1p562

\begin{abstract}
Street children do not have a solid mental emotional yet, but they have to deal with a tough street world, competitive, and tends to affect negatively to the development of their personality. The presence of the street children on the streets are not only motivated by economic factor, but also influenced by the disharmony in the role and functions of the family and the influence of the social environment. The empowerment of street children that has been done by the shelter was not yet carried out effectively. This study aims to identify problems that are experienced by street girls, to describe efforts to overcome the problems experienced by street girls, and to develop a model of empowerment for street girl in Surabaya who do not occupy a shelter. This study used a qualitative method, where data is collected through participation observation and in-depth interviews. The data were analyzed using qualitative analysis model of Miles and Huberman. The problems of street children were often experienced by girls, such as violence. Then, the problems led to survival mechanisms. In addition, the emerging imitation behavior as a response to the behavior that directed to them. The parents also play a role in the process of social control. The empowerment model that designed is the empowerment of education through the revitalization of the family. Additionally, creating access to formal education for the street girl through scholarships mechanism. Life skills education needs to be strengthened to improve the welfare of living.
\end{abstract}

Keywords: development model; street girls;empowerment.

\section{Introduction}

Street children are children who are at a certain level do not have a solid mental emotional constructions yet, while at the same time, have to deal with a tough street world, competitive, and tends to affect negatively the formation and development of the child's personality. Street children are a part of Social Welfare Problems / Penyandang Masalah Kesejahteraan Sosial (PMKS). PMKS is a person, family, or group of people which because of an obstacle, difficulty, or distractions can not perform their social function so that their needs are not met, either physically, spiritually, and socially adequate and reasonable. Obstacles, difficulties, or the disorder may include poverty, neglect, disability, social disability, retardation, isolation, and natural or social disaster (Ministry of Social Affairs, 2013: 25).

Street children within the framework of the Ministry of Social Affairs (2009: 10), defined as children aged 5-18 years who spends most of their time to make a living and roaming the streets and public places. In line with the definition of the Ministry of Social Affairs of the street children, The United Nations International Children's Emergency Fund (UNICEF) defines street children by the age limit below 16 years old that had escaped from families, schools, and communities, as well as dissolved in the nomadic life on the street. Many definitions related to street children put the position of street children as a marginal and vulnerable groups with various risks.

The data of Ministry of Social Affairs in 2012, states that the number of street children in Indonesia reached 94356 children, with the province of East Java as the province with the largest population of street children, namely 2,870 children, consisting of 2,262 boys and 608 girls. This amount, according to the data of Social Service of East Java province showed an increase from the previous year (2011) i.e. 2.224 children. Street children in the city of Surabaya itself declined from 795 children in 2011 to 790 children in 2012 (Ministry of Social Affairs, 2013: 12). Given the high number of street children, whether at the national level, provincial, and district/city, the problems surrounding the street children become very comprehensive and require a special handling. 
The presence intensity of the street children on the streets are not only motivated by economic factor, but also influenced by other variables, such as the massive violence in the family, disharmony in the role and functions of the family, as well as the influence of the social environment (Subhansyah, 1996: 14 ). The guarantee of rights of the children as the fulfillment of human rights in general and this is firmly protected in the constitution, as stated in the Undangundang 1945, Undang-undang No. 39 of 1999 about Human Rights, Undang-undang No. 23 of 2002 about Child Protection, and the Decree of the President of the Republic of Indonesia Number 36 of 1990 on the ratification of the Convention on the Right of the Child .

However, the fulfillment of street children's basic rights today is still far from the expectations. This condition is clearly illustrated at least from the phenomenon of street children and the social impact. The street children, especially street girls are particularly vulnerable to various forms of exploitative treatment, both economically and sexually. Sociologically, the presence of girls in the street viewed negatively by most of society and is often labeled as a naughty girl that has negative connotations and tends to connote involved in prostitution. Stereotypes and negative stigma that are labeled on the street girl are getting stronger. Therefore, in the context of parenting efforts, handling, and empowerment of the street girl, the stigma needs to be changed. The existences of street girls need to get serious attention.

During this time, the handling and the empowerment of street children, especially the street girl, have gotten responses from various parties, both the government agencies and non-governmental agencies, such as the Non Governmental Organization (NGO) / Lembaga Swadaya Masyarakat (LSM) through shelters. However, they have not run optimally and effectively. The field findings showed that the empowerment of street children through the shelter program had not run effectively. The findings of Effendy, Frieda, and Hardi (2008: 40-45), showed that there were some problems of their shelters for street children. First, the performance of the shelters' management officers was not optimal, because of the lack of support for the activities of human resource development through participation in courses and training and social work functional training. Second, the pattern of handling street children through shelters had not fully refers to the guidelines outlined by the Government (Ministry of Social Affairs), due to the lack of consistency in performance achievements of the shelters, both in terms of the implementation of the officer's performance, street children and shelter material support infrastructures. Third, the absence of mentoring system of street children and the effective advance coaching after that were resulting in the vulnerability of the street children's condition from the influence of the social environment. Fourth, the inadequate support of infrastructure for street children's activities because of home ownership limitations were resulting the number of street children who stay and follow the service activities in the shelter decrease.

Therefore, this research focuses on the street girls who do not occupy a shelter. In the first year, it aims to identify problems faced by the street girl, to describe efforts to overcome the problems faced by the street girl and to develop a model of empowerment for the street girl in Surabaya who do not occupy a shelter.

\section{Review of Related Literature}

The research on parenting and the empowerment of street girl become the focus of an interesting study in the study of gender. A research by Murshid Itsnaini (2010: 65-72), about "The Street Children Empowerment by Kawah Shelter in Klitren village, Gondokusuman, Yogjakarta", explained that the existence of Kawah Shelter had given a great influence on the street children in the shelter. This condition was clearly visible with their existing programs to empower street children so the aim to shape the attitudes and behavior of children in accordance with the values and norms prevailing in society, as well as to provide an early education to meet the needs of children and to prepare a future generation could become more effective and go along well.

A study by Maria April Astuti (2011: 50-55), about "The Street Children Empowerment in Jakarta: A Case Study in Setia Kawan II Shelter in Jakarta", revealed that the empowerment program implemented by Setia Kawan II Shelter in Jakarta had been carried out in a holistic manner. It was proven from the participants of the program including the street children and the parents of street children. The program was intended to empower the street children and the parents of street children to increase their ability so that through their participation in the empowerment programs, they could be independent and able to meet their everyday needs as well as the children were not allowed to move further down the road.

However, due to this empowerment program was carried out by the collaboration between the Ministry of Social Affairs and UNDP which lasted only 3 (three) years, since 1997- 2000, after the pilot program ended, the empowerment activities of street children and the parents of street children could not be resumed. In addition, because the participants of the program were limited, thus not all the parents of street children and the street children could enjoy the occasion. Because the handling process was only for a while and did not seem sustainable, but the problems of street children were quite a lot, these activities should be resumed again. The consideration was because the children who join 
the program could be independent and did not do the activity in the street anymore. In terms of parental or family, their life could be increased more because the growing problem of street children could not be separated from their family condition. Therefore, if the family or the parents of street children have the ability to meet the needs of family members, the problems of street children can be reduced.

While a research by Purwayuli (2010: 74-83) about "The Effort of Street Girl Development: A Case Study of Violence for Street Girls in South Semarang", found an interesting findings that the lives of street girls were often abused. The development efforts undertaken by the shelters and the street girls' companion was by recruitment or gathered together, then they were given knowledge about the impact or the danger on the road and corresponded to the needs of the children with the aim of reducing the children's time in the street.

The kinds of violence experienced by the street girl are economic violence, physical, sexual, psychological and neglect from parents. While the abusers are the people around the street girls, they are the parents, the raid officers, school friends, thugs and the unknown person. The impact in the short-term and long-term gives effect on the psychological development of the street girl.

In addition, a research on the effectiveness of the shelter as a strategy for empowering street children has also been conducted earlier research, such as a research by Effendy, Frieda, and Hardi (2008: 40-45) on "The Evaluation of Street Children Handling in Homeless Shelter in Semarang", showed that there were some problems of the existence of the shelters for street children. First, the performance of the officers' shelters management was not optimal, because of the lack of support for the activities of human resource development performance through participation in educational courses and training courses as well as social work functional training. Second, the ways of handling street children through shelters had not fully refers to the guidelines outlined by the Government (Ministry of Social Affairs), due to the lack of consistency in shelters' performance achievements, both in terms of the implementation of the officer's performance, street children and shelter infrastructures supports.

Third, the lack of guidance system of street children and an effective advanced coaching after the shelters coaching, resulting in the vulnerability of the street children's condition from the influence of their social environment. Fourth, the infrastructure was not optimally support the activities because of the shelter home ownership limitations, resulting in inadequate number of street children who stay and follow the service activities in the shelter.

A research conducted by Laila Sakina (2011: 63-73) about the "The Assessment of Street Children on Shelter Home Care and Its Relationship With Their Behavior: The Case of Bina Pertiwi Children's Shelter Home, Jati Padang Village, Pasar Minggu, South Jakarta", discovered an interesting fact that the empowerment of street children through shelter had not made it as an assessment and a referral center as well as facilitator. The shelter's coach had not been responsive in solving the problems perceived the target children. Moreover, the relations of target children with their families, as well as other institutions were also not maximized. The government only focused on increasing the number of shelters, while the quality improvement had not been the first priority.

Street children are children who excluded, marginalized, and excluded from the treatment of affection. This is the result of their habit to deal with the harsh and unfriendly environment. Street children are considered marginal because they do the kind of work that the career level is not clear and underappreciated, vulnerable because the risk of the working hours that should be taken is very vulnerable, and exploitative because they have a very weak bargaining position, so it tends to be the object of arbitrary treatment from thugs or irresponsible apparatus.

Street children (including the street girls), defined as children who spend most of their time on the streets and they are nomadic. Their activities are usually begging, busking, wiping car or motorcycle, shining shoes, selling newspapers and other activities as long as they earn money. The characteristics of street girls are those who aged 12 years old on average, each day they spend their time on the streets to work or just hang around on the streets, most of them are dirty and dull as well as their clothes are slovenly and irregular (Shalahudin , 2002: 20-22).

Street girls survive by building solidarity, economic activity, utilizing thrift, crimes, and engage in activities that are vulnerable to sexual exploitation. As for the characteristics of the street girls, i.e.:

1. Street girls use the street as a place to live, play, work, and do any kinds of activities that they consider profitable and make money;

2. Street girls live in the roadside, hallways shop, city park, in a doorway or houses that they consider big and are usually located on the side of the road;

3. Street girls get their own food by purchasing their own from the work, begging, busking or obtaining from the donors; and

4. The income they get is usually used to finance the cost of their lives and it is not uncommon to defray the cost and living of the family as well, for savings, and not infrequently to finance the cost of their own school.

According to the 1945 Constitution (UUD 1945), Article 34 (Pasal 34), that "the abandoned children are maintained 
by the state," meaning that the government has a responsibility for the maintenance and development of the abandoned children, including the street girl. The classification of street girls based on their relationship with the family, i.e.:

1. Children on the street, meaning the street girls who have economic activities on the road that still has a relationship with the family. Children on the street are divided into two, namely:

a. Street girls who live with their parents and always come home every day; and

b. Street girls who perform an economic activity and live on the streets, but still maintain a relationship with the family.

2. Children of the street, meaning the street girl who spend all or most of her time on the street and does not have a relationship with the family. These street children have break off their relationship with their parents, so they spend all of their time on the street that come from the families who live on the streets.

The factors causing the emergence of street girls are classified into two, namely:

1. Internal factors

a. Laziness and unwilling to work;

b. Any biological and psychological defect. Hereditary defects that are biological, namely the lack of functioning organ to produce, while the psychological defects is a lack of functioning mental and behavior to socialize in the community;

c. There are no hobbies. A child who does not have a healthy hobby or positive avocation to fill his spare time, then it is easy to do a negative action;

d. The inability to adapt to a good and creative environmental changes, thus it gives a rise to immorality;

e. The dream of freedom. Various problems faced by children in the family can lead to rebellion within them and tried to find a way out. A child feels bored and miserable at home because every day watches his/her parents fight and does not pay attention to them, eventually the child will pick to the streets because they feel that they have a freedom and have many friends who could hold her complaint;

f. The desire to have their own money. Differ by the factor of encouragement from parents, money that is earned by the children usually used for their own purposes. Although the children give some money to the parents, this is voluntarily and has no adverse effect on the child if they do not give some money to the parents or family.

1. External Factors

a. Family encouragement, where in this case, the family is usually the mother or sister. Both are parties who contribute to motivate the children to go into the streets. Usually the motivation of the family are by bringing the children to go to the streets to help their parents work and sending the children to carry out activities in the streets that earn money;

b. The influence of friends is one factor that causes the children to go into the streets. The influence of friends showing a big impact of the children to go into the streets, particularly if the motivation to go to the streets is to get the support from parents or family; and

c. Violence in the family expressed as one of the factors which motivate the children to run away from home and to go into the street. Violence that is done by the family members to the children can indeed occur in all social strata of society. However, at the low level society stratum, likelihood of violence will be greater and the type of violence is more diverse.

The Study Report on Violence against Children, released by United Nations, August 29, 2006, said 53,000 children have died in the worldwide in 2002 as a result of homicide. Children who experienced homicide, as many as 22,000 (42\%) aged 15-17 years old and of that number $75 \%$ were boys. Besides that, there is $80-98 \%$ experienced physical punishment. Around 150 million boys aged 18 years old experienced sexual violence or other forms of violence during 2002.

Study centers even noted that the increasing levels of violence against street children are quite striking from year to year. The Commission of National Child Protection / Komisi Perlindungan Anak Nasional noted that during JanuaryApril 2007, there were 417 cases of violence against street children. The cases include physical violence (89 cases), sexual violence (118 cases), and psychological violence (210 cases). In the same period, the previous year showed 247 cases of physical violence, 426 cases of sexual violence, and 451 cases of psychological violence. Research, program reports, the results of monitoring, and the mass media have revealed bad situations experienced by the street children in Semarang.

PAJS monitoring (1997) in the area of Tugu Muda in the period of July to December 1996, the record of 22 cases of violence against street children, 19 cases $(86.3 \%)$ carried out by security personnel (police, municipal police, and military) that supposed to provide protection against them. The same thing were also expressed in the research report of 
YDA (1997) which states that the greatest danger is most often experienced by street children were chased by the police, in which $91 \%$ of children who had been caught claiming to have been tortured.

Other violence is hostility and sexual exploitation. Almost all the street girl had experienced sexual harassment especially for children who live in the streets. When sleeping, they often become the victims of their friends or street community, for example groping the body and genitals. Another form of violence is rape. Setara (1999) in his report stated that $30 \%$ of the street girl had the first intercourse as a result of rape. Not infrequently a rape is committed by a group of people (Permadi and Ardhianie, 1997: 10-15).

The empowerment of women is defined as a series of attempts for woman to gain the access of welfare, the opportunity to participate as a subject of development, to give a decision, and as a function of control over economic resources, political, social, and culture so that women can measure the ability of herself and able to participate actively in the development. Therefore, the goal of women's empowerment is directed to develop and finalize the potential that exists, including accessing information.

Stewart (in Nugroho, 2008: 34) provides the preconditions in the empowerment of women, namely the provision of expertise and equips certain skills; giving roles and opportunities; and the provision of facilities and services to realize such capabilities. Women's empowerment can be done through the organization and mobilization of local resources. Organizing the activities to empower women is usually done in two levels. First, at the community level such as the formation group of women who become critical consumers and producers of daily necessities for themselves, family, and their community. Secondly, at regional and national level through the establishment of a network organization that can give political power for women.

The empowerment of street girls in this study will be directed to the potential development of the street girl, i.e.: the potential in the field of art and entrepreneurship skills. The identification result of potential on the street girl will be followed up by providing technical training skills to further increase potential and the skills of the street girl. The results of technical training skills will be implemented by opening the productive unit that can be developed independently by the street children.

\section{Research Methods}

This research was conducted using qualitative methods. Qualitative research method is a research methods that intended to understand the phenomenon of what is experienced by the research subjects. This study took place in Surabaya because most of the street girls' distribution was in East Java.

The subjects in this study were street girls, Non-Governmental Organization (NGO) / Lembaga Swadaya Masyarakat (LSM) which handles street girls, and the officer of Lingkungan Pondok Sosial (Liponsos) Surabaya.

The data were collected through two ways, namely extracting primary and secondary data.The primary data collection was done through participant observation and in-depth interviews. The secondary data was done by tracking the books; scientific articles, both published by the journal; media reports; and research results related to the problems of the study.

The analysis of the data used in this study was qualitative analysis model of Miles and Huberman, through data reduction techniques, data presentation, and verification.

\section{Results and Discussion}

\subsection{The problems experienced by the street girl}

Street children (including street girls), defined as children who spend most of their time on the streets and where their existence are also never certain and the activities they do to make money. The characteristics of the street girl are those who aged 12 years old on average, everyday they spend their time on the streets to work or just hang around on the streets, most of them are dirty and dull appearance as well as their clothes are slovenly and irregular (Shalahudin , 2002: 20-22).

However, the problems were often experienced by the street girls when working on the streets. Based on the field data retrieval, there were street girls who experienced violence while busking, where the money from busking were robbed by thugs. Although then the thugs then arrested and reprimanded by the citizens. The street girls were used to busk after school.

If it was still under parental supervision, the street girl were rarely hassled by thugs. There was a unique discovery, where there were street children who actually had a strong desire to go to school, but the parents forbade them to go to 
school because it was associated with the economic burden of the parents. In addition, if the children go to the school, it will hinder the work on the streets, which in turn also reduces the income that they should get.

\subsection{The efforts to solve problem of street girls}

Various problems were often experienced by street girl which consequences on the efforts to resist the emergence of these problems. Based on the research data in the field, the street girls have a unique strategy, including, if they got abused during their work on the street, then they save themselves. However, if in a deserted area and the money was asked by the thugs, the street girl tend to give the money to the thugs because they were afraid of being tortured. The response of parents when their children got violence, they would be angry and approached the people that had disturbed their children.

If the street girl got a trouble from thugs, then the first action that was performed would shout for help to anyone who was around her. There were also street girls who reported the incident that happened to their brother who was with them.

When their friends, the other fellow street children were being naughty to them, then the street girl tend to be naughty. There was a behavior that was imitated by the street girls as a response to the action that was directed to them. In fact, some of the street girls had their own way to avoid violence while busking in the street. Some of the strategies were after they finish busking they usually taken a short break by riding a bike. In addition, to avoid the other violence, the street girls also maintained their behavior to avoid interferes with other people.

Parents also play a role in the process of social control. Some street girls claimed that when there was violence or an injured by a friend in the street, then the parents would approach the person and conduct a similar resistance.

\subsection{The model of street girls empowerment}

Street girls who were interviewed appeared to have ideals outstanding. Among the street girls, there was an aspiring to become a teacher so keeping a strong motivation to continue their studies to a higher level course at a very affordable cost. Even the money that had earned from work on the streets they set aside as much as possible in part for educational savings. However, there were also street girls who gave the money from busking to their mother.

There were also street girls who aspired to be a doctor. If the cost was available, they wanted to get a higher school, at this time they wanted to continue to junior high school first. If the cost was available, the street girls preferred to learn in public schools rather than learning in a shelter. Informants themselves feel comfortable with the current position.

However, there were also parents who opposed their children to school. Street girls actually wanted to go to school, but it was opposed by their father because their father did not agree when they go to school because according to the father's informant it was bothering him to earn money.

Therefore, the model of empowerment which was designed in accordance with the findings of the data was the empowerment of education. First, the parents or families of the street girls must be strengthened by an understanding of the importance of formal education for their children. Working on the streets were not intrusive the formal education process that they followed. After the understanding about the importance of education had been firmly entrenched in the parents' ideology of the street girls, the second step was to create the widest possible access so that the street girls could enjoy an adequate formal education. Scholarship mechanism should be widely provided. Formal education that undertaken by the street children should also be supported by strengthening of the life skills with the orientation on the economic results to improve the welfare of living.

While the second problem faced by street children, where parents often forbid even hinder his desire to go to school. Street children women actually have a strong desire to go to school. They hope that the money they collect from busking or begging on the streets they save for the purposes of school fees. However, their parents actually judge that going to school is very hard effort and it could not be done due to the limited economic capacity of parents. The money from busking and begging was actually used by the parents of street children (especially their mother) for consumptive activities, such as buying food, beverage, or other goods that are favored by their parents (their mother). So practical, their hope to school in formal educational institutions is hampered and only become a wishful thinking.

However, they could smile a little because there are still non-formal education that could be used by street girls to learn. One strategy they employ is to take the advantage of used books to read in their spare time. Some learning activities on the streets ever held by some NGOs Education in Surabaya often used by female street children. Even though they do not live in a halfway house, they often stopped at a halfway house with their friend for reading a book in the shelters library or studying together in a halfway house. In addition, the need for special scholarships from the 
Government of Surabaya for the street girls who want to school. The following is the development model framework of empowering street girls who do not occupy a halfway house in Surabaya.

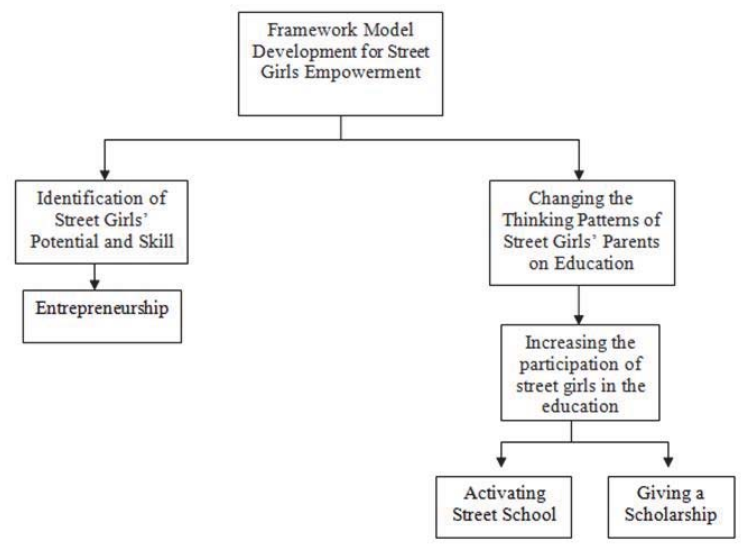

Figure 1. Framework Model Development for Street Girls Empowerment

\section{Conclusion}

The various problems are often experienced by the street girl, such as violence when singing. The problems of the street girl then led to the effort to survive, such as saving themselves by giving the money to the thugs. The response of the parents when the children get violence they will get angry and approach the people who are disturbing their children. When their friends, the other fellow street children are being naughty to them, then the street girl tend to be naughty. There is a behavior that is imitated by the street girls as a response to the action that is directed to them. The parents also play a role in the process of social control.

The empowerment model that is designed in accordance with the findings of the data is the empowerment of education. First, the parents or families of the street girls must be strengthened by an understanding of the importance of formal education for their children. Second, creating the widest possible access, thus the street girl can enjoy an adequate formal education. Scholarship mechanism should be widely provided. Formal education that undertaken by the street children should also be supported by strengthening of the life skills with the orientation on the economic results to improve the welfare of living.

\section{References}

Astuti, Maria April. 2011. Empowering street children in Jakarta: A Case Study in Shelter Setia Kawan II Jakarta.Jakarta: Indonesia University.

Layman, Ambassador. 2007. Annual Report Layman Foundation Ambassador Semarang.Semarang: Layman Foundation Ambassador.

Effendy, Noor Mohammad Natsir, Frieda NRH, Hardi Warsono. 2008. "Evaluation of Handling Street Children In Homeless Shelter in Semarang".Dialogue, Journal of Administrative Sciences and Public Policy, Vol.5, No. 1, January 2008. Pages 137-154.

Itsnaini, Murshid. 2010. "Street Children Empowerment By Crater Shelter in Klitren Village, Gondokusuman, Yogyakarta".Unpublished thesis.Yogyakarta: Islamic State University of Sunan Kalidjaga.

Ministry of Social Affairs. 2009. Data with social welfare problems Potential and Social Welfare in 2009. (On line). (Http://database.depsos.go.id/modules.php?name = Pmks2009 \& option = pmks2009-2. Accessed May 8, 2013).

Moleong, Lexy J. 2010. Qualitative Research Methods.Bandung: Young Rosdakarya.

Nugroho, Riant. 2008. And gender-mainstreaming strategy utamaannya in Indonesia.Yogyakarta: Student Library.

Permadi and Ardhianie.1997. Violence Against Street Children.Jakarta: Gramedia Pustaka Utama.

Purwayuli. 2010. "Street Girls Development Effort: A Case Study of Violence for Street Girls in South Semarang Region". Unpublished thesis.Semarang: Semarang State University.

Sakina, Laila. 2011. "Assessment of the Street Children's Home Care Shelter and Its Relationship With Those Behavior: The Case of Children's Home Bina Pertiwi Shelter, Jati Padang, Pasar Minggu, South Jakarta". Unpublished thesis.Bogor: Institut Pertanian Bogor.

Saladin, Odi. 2000. Street Girls fate.Yogyakarta: Home Publishing. 
Subhansyah, Aan, et al. 1996. Street Children in Indonesia: Description and Management Issues. Yogyakarta: LPSH Humana. United Nations International Children's Emergency Fund (UNICEF).2013. UNICEF Report 2012.UNICEF: Washington.

Wandy, Darmawan. 2008. Street Children's Map Problem Solving and Model Alternatif Based on Family Empowerment.Jakarta: LP3ES. 